\title{
Bioconversion of Vegetable and Flower Wastes into Compost by Eudrilus euginae Treated with Food Colouring Agent Tartrazine
}

\author{
Kalaivanan, K., Durairaj, S. and Selladurai, G. \\ P.G. and Research Department of Zoology, Aringer Anna Govt. Arts College, Cheyyar, \\ Tiruvannamalai, Tamil Nadu.
}

\begin{abstract}
Waste materials in recent years have been increasing day by day and it is a major threat to the environmental issue. To solve the problem in one way, the waste materials are utilized in a fruitful way by using Eudrilus eugeniae. The vegetable and flower waste were subjected to vermicompost separately and along with tartrazine treatment. In these treatments, the vermicompost materials were analysed the micro and macro nutrients to understand the impact of tartrazine on the bioconversion of waste into compost. The Nitrogen level was increased in the flower waste compost by $28.5 \%$ whereas it was decreased in the vegetable waste by $28.6 \%$. Similarly, the decreasing trend of Phosphorus was observed in both the compost. Besides Nitrogen and Phosphorus, the Potassium showed significant increase in all the treatments. However, insignificant changes of Zinc, Manganese and Copper were observed in the compost of flower and vegetable waste. In the case of Ferrous, significant increase was observed. The physical properties such as the Electrical Conductivity (EC) and $\mathrm{pH}$ of the vermicompost showed almost equal to the control. On the Basis of observation, the nutrients of the compost of waste have been stabilized by the earthworm, E. eugeniae.
\end{abstract}

Keywords: Earthworms, Tartrazine, Vermicompost, Vegetable and Flower waste.

\section{Introduction}

A rapid increasing population and high rate of industrialization has increased the problem of solid waste management [1]. The large amount of solid waste and sludge produced by anthropogenic sources is becoming a serious problem [2]. Proper waste management is very crucial and has become the main challenge in many countries [3]. Vermicomposting has become an appropriate alternative for the safe hygienic and cost effective disposal of wastes. Earthworm is an eco-biotechnological process that transforms energy rich and complex organic substances into stabilized vermicompost [4]. Recycling of wastes using earthworm has become an important component of sustainable agriculture which has a multidirectional impact in terms of safe disposal of wastes preventing environmental pollution besides yielding nutrient rich material [5]. The environmentally acceptable vermicomposting technology using earthworm can well adopt for converting waste into wealth [6].

The earthworms have been fortunate to degrade wastes and turn them into a fertilizer which is popularly termed as vermicomposting; thus acquired product is recognized as vermicompost. It is the resourceful technique to renovate the biological wastes (human discarded, kitchen surplus, animal left-over etc.) into a biological fertilizer. Edwards and Burrows [7] reported that vermicompost has an abundant fine structure than outmoded mucks and it is highly saturated with nutrients which are freely available for plants intake. Even vermicompost is rich in both the bacterial components [8] and fungal profusion [9] than the outmoded muck. Earthworms are used for refining and preserving soil fertility, change of organic waste into a useful fertilizer, for livestock [10] then bait used for fish. Increasing civilization and urbanization has vermicomposting is a mesophilic process led to an everlasting generation of wastes, carried out by earthworms, involves there by polluting the environment from ingestion, digestion, and absorption of the various sources. Disposal and environmental organic waste followed by excretion of friendly management of these wastes are castings through the worm's metabolic becoming a serious global problem.

\section{Collection of Earthworms}

\section{Materials And Methods}

The earthworm Eudrilus eugeniae, were collected form Chithathur, Thiruvanamalai Dt, Tamil Nadu, the collection of earthworm was brought to laboratory for acclimatization. The present study was carried out between June - August 2016 in the Zoology laboratory. The selected Flower and Vegetable waste were collected from Vembakkam market. Separate mixed thoroughly with $2 \mathrm{~kg}$ of soil. This mixture was placed in the form of heaps under shady place. Watering was done regularly twice in a day in order to maintain the optimum temperature and moisture. This set up was maintained for 30 days. In another pot the same mixture was taken with tartrazine (a food colour chemical) then released earthworm. Suitable control was maintained. Similarly flower waste was also taken separately in another pot. The waste mixtures were allowed to pass through 
earthworm guts for vermicomposting. The moisture content of the organic substrates in each pot was maintained between $60 \%$ and $65 \%$ throughout the study period by sprinkling water after every 24 hours. The experiment was conducted by randomized design with three replications. In the vermicompost materials the experimental set up was maintained till 25 days. After was the compost material was selected to micro and macro nutrient analysis total nitrogen $(\mathrm{N})$, total phosphorus $(\mathrm{P})$, total potassium $(\mathrm{K})$ Zinc $(\mathrm{Zn})$, Manganese (Man), Iron (Fe), and Copper $(\mathrm{Cu})$, were analysed in the control and experiments separately.

\section{Histological Studies}

The histology of anterior, clitellar, meddles and posterior regions of earthworm were studied by adopting the routine paraffin method. The control and experimental animals were blotted free of mucus, washed thoroughly in physiological saline, cut into pieces of clitella region of desired size and fixed in Bruin's fluid fixative immediately after autopsy. Fixation was carried out at room temperature for $24 \mathrm{hr}$, after which the tissues were transferred to $70 \%$ alcohol. Several changes of $70 \%$ alcohol were given until the yellow colour disappeared from the tissues. The tissues were then dehydrated by passing through ascending graded of alcohol, cleared in xylene, infiltrated with molten paraffin, and finally embedded in paraffin wax. Tissue section of 5- $\mu \mathrm{m}$ thick of cross sections were obtained using a rotary microtome. The section, thus obtained, were stained in harries haematoxylin and eosin, dehydrated using alcohol, cleared in xylene and mounted using dihydroxy phthalate xylol (DPX).

\section{Results}

The vegetable and flower waste of different proportions were mixed with vermibed and seen the efficiency of the earthworm in the conversion of vegetable and flower waste into minerals on 25 day. Along with this, tartrazine was treated with the vegetable and flower waste as an experiment. The experimental setup was arranged which was follows; control, tartrazine with vegetable and flower waste of known weights taken separately. The weight of vegetable and flower waste was 100 gms. Mean number of days required for the biotransformation of waste into vermicompost was 25 days. The nutrient status of vermicomposting depends on the type of waste material processed by earthworms. An increase in the values was observed in the following parameters such as total Nitrogen $(\mathrm{N})$, Total Phosphorous $(\mathrm{P})$, and Total Potassium (K), in the different treatments of vegetable and flower waste when compared to control, however the significant decrease was observed in tartrazine treated vegetable and flower wastes.

\section{Physico-Chemical properties}

The cow dung used as the inoculants in the vermicomposting process enhanced the quality of feeding resource attracting the earthworms and accelerated the breakdown of wastes resulting in the reduction of increasing certain nutrients. The analysis of Nitrogen $(\mathrm{N})$, Phosphorus (P), Potassium (K), Iron (Fe), Manganese $(\mathrm{Mn})$, Zinc ( $\mathrm{Zn})$, Copper $(\mathrm{Cu})$, Electrical Conductivity (EC), and $\mathrm{pH}$ were analyzed on 25 days in the control, tartrazine treated vegetable and flower waste. In the control, the $\mathrm{N}$ value was $70 \%$ and this level decrease in the tartrazine treated where as in the other treatment, the level of $\mathrm{N}$ was increased gradually. All the values were statistically significant at $\mathrm{P}<0.01$. The maximum of $35 \%$ increase of nitrogen was noticed in the 100 gms vegetable waste then $4 \%$ and $9 \%$ increase of nitrogen as noticed in the 100 gms flower waste. Equally in the tartrazine treatment also noticed in the level of nitrogen was slightly increased. All the values were statistically significant $\mathrm{p}<0.01$. The maximum of $35 \%$ in the tartrazine treated also noticed, the level of nitrogen was decreased to $28 \%$ on $25^{\text {th }}$ day, indicated the decreased of $\mathrm{N}$ level. The study indicated that the optimum level of mineralization takes 25 days. Similarly, $\mathrm{P}$ was also decreased only in the treatment where the level was $75 \%$ and showed insignificant at $\mathrm{P}<0.05$ (Fig.1 to 13 ).

The vermicompost was dark brown in colour and homogenous after 45 days of earthworm's activity. The changes in worm biomass for all the treatments over the experimentation period were observed. At the end of the $25^{\text {th }}$ day, the earthworm biomass had increased in all the treatments. A decrease in the value of $\mathrm{N}$ was observed in the vegetable treated with tartrazine following parameters Nitrogen when compared to control. In the flower waste treated tartrazine, this is increase of 20 and $28 \%$ similarly phosphorous was also decrease in $\mathrm{V} 2$ treatment where as $\mathrm{P}$ revealed significant correlation in $100 \mathrm{gm}$ treatment vegetable and flower waste. In contrast to NPK showed in significant when compared all other treatments. The analysis of Fe, Mn, $\mathrm{Zn}, \mathrm{Cu}$ were also increased same level treatment with $100 \mathrm{gms}$ and of vegetable waste similarly the same end was also absured in the flower waste. Similar by $\mathrm{Fe}, \mathrm{Mn}, \mathrm{Zn}$, and $\mathrm{Cu}$ were also showed significance of $100 \mathrm{gm}$ treatments. On 25 days analysis, Fe showed increase in all the treatments when compared to control. Mn also indicated the slight increased in all treatment on 25day. Similarly $\mathrm{Zn}$ and cu were also increased significant in the 100 gms of vegetable waste treatments at $\mathrm{p}<0.05$ level (Fig. 1 to 13 ). 

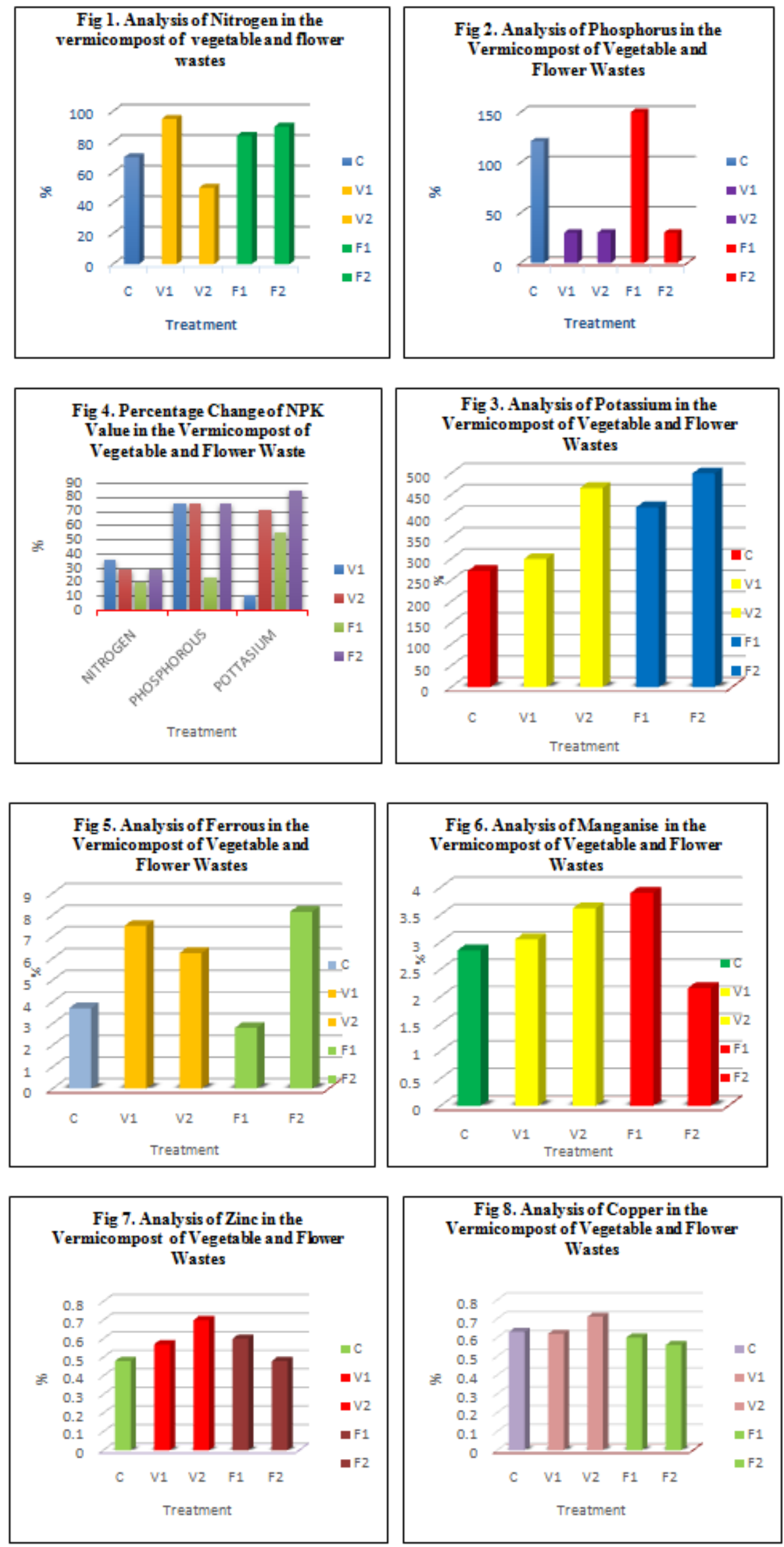

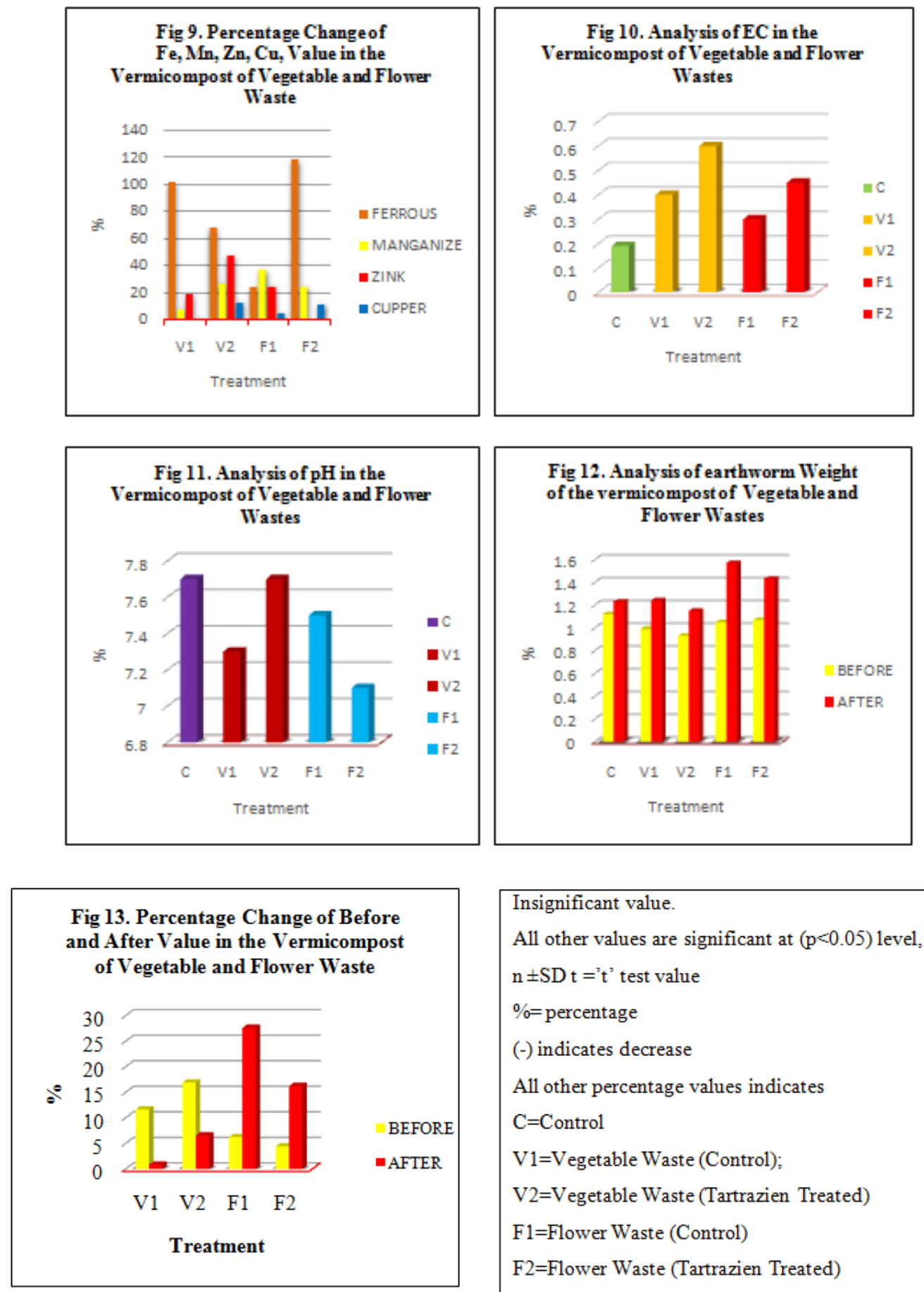

Physico-chemical properties of the soil mixed with different vegetable and flower waste were analysed on 25 days along with control and experiment. The EC was increased from 100gm treatment including tartrazine treated vegetable wastes. However the was two increase in to flower waste. The increased in all the treatments were statistically significant at $\mathrm{P}<0.01$ level (Fig. 1 to 13). Among the different treatments on 25 days, $\mathrm{pH}$ value was normal and no change was observed in the tartrazine treatments and indicated statically insignificance. In this study, a reduction in the $\mathrm{pH}$ was recorded at the end experiment. The variability in $\mathrm{pH}$ could be due to the production of organic acids during organic waste decomposition. During their study on the vermicomposting some organic residues may be produced that could have lowered $\mathrm{pH}$ level at the end of experiment. The analysis on 25 days showed reduction of $\mathrm{pH}$ value in all the treatments, and showed in significance. The bioconversion of these waste will be completed in about 25-35 days or even a lesser than this time limit. Figure showed the weight gain of earthworm, in the all the treatments lower the little increase in weight showed statistically insignificance. 


\section{Histological Studies of Earthworm Eudrilus eugeniae}

The cross section of Fore gut (anterior and clitellar region), Mid gut (middle region), Hind gut (posterior region) of control, tartrazine treated and vegetable and flower waste treatments of higher proportion were taken to study the anatomical features of Eudrilus eugeniae. In the control animal, the epidermis of the Eudrilus eugeniae consists of an epidermal epithelium and an overlying fibrous cuticle. Below the epidermis, circular and longitudinal muscles were intact and from the body wall the coelom was clearly seen. Along with this, luman blood vessels chloragogen cells were seen clearly. Below the epidermis, the pigment cell was numerous. The tartrazine treated section of clitellar region showed less change when compared to control. The size of the blood vessel was reduced. The cuticle, epidermis and circular muscles were not changed in the experiment.
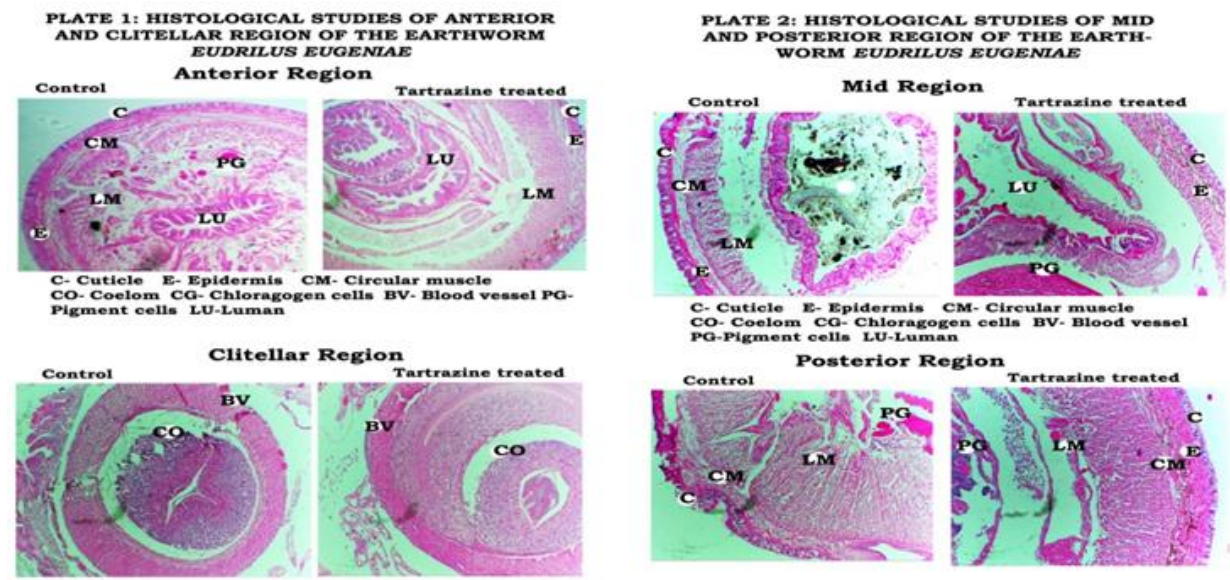

However, the coelom was enlarged. The supposed to be the pigment cells were reduced to a greater extent. Region showed very little changes. Similarly in the tartrazine treated clitellar region showed very little changes in the luman, blood vessels and pigment cells. The intestinal epithelial lining, the lumen of the intestine are also damaged. Greater degree of injury to the dorsal and ventral blood vessel is observed. Ventral nerve cord is damaged beyond recognition. In short, the acute concentration of distillery sludge has a telling effect on the histology of the earthworm E. eugeniae. In the tartrazine treated and vegetable and flower waste treated sections were less affected. Inter vascular space was much reduced. Majority of the anatomical details were intact except few changes like the size of the luman, number of the pigment cells and the size of the coelom. Only in certain regions the thickness of the body wall was reduced. The vegetable and flower waste and tartrazine were not much impact on the anatomy of the Eudrilus eugeniae.

\section{Discussion}

Food requirements play an important role in the growth and reproduction of earthworm population which depends on both physical and chemical properties of the soil, such as soil temperature, moisture, $\mathrm{pH}$, salts, aeration and texture, as well as available food. Maximum growth of Eudrilus eugeniae grown in 100\% cow dung. Further, they have observed that earthworms grew and reproduced favourable up to 1:1 press mud and cow dung feed composition. The present finding is in good accords with those of [11] that have registered increase in $\mathrm{N}$ and $\mathrm{P}$ in vermicompost employing $E$. eugeniae and have suggested that vermicomposting could be an alternative technology for the management of $\mathrm{pH}$ into useful fertilizer material, if mixed at maximum 50\% with cow dung. Micronutrients like $\mathrm{Zn}$ content elevated, whereas Fe and $\mathrm{Mn}$ declined effect in flower waste compost. No considerable change in the $\mathrm{Cu}$ content of the vermicompost was observed in both vegetable and flower waste compost. On the other hand, during the composting process, micronutrients like $\mathrm{Zn}$ and $\mathrm{Cu}$ elevated. There was no drastic difference in the manganese content before and after composting. In contraction to the present observation, [12] have recorded $\mathrm{Cu}$ content (78.32 ppm) with vermicomposting $100 \%$ bagasse. Increase in the $\mathrm{Zn}$ content of the vermicomposted bagasse gains support from the observation of [12] that has also registered maximum $\mathrm{Zn}$ content of 245-61 ppm in bagasse (100\%) vermicompost.

During the composting period nitrogen, phosphorous and potassium contents were measured. Generally, vermicompost was found to be rich in nitrogen and phosphorous and had good structure, low conductivity, high humic acid contents as well as good stability and maturity. Similarly, we also observed high content of nitrogen and phosphorous with good texture in the vermicompost. Nitrogen and phosphorous contents were dramatically increased in the vermicompost due to the impact of earthworms and the presence of cow dung. Recently, [13] reported that nitro potassium was enriched in my cost raw and cow dung based vermicompost compared to controls without earthworms. [14] Conducted an experiment in vermicomposting 
using turkey litter and cow dung mixtures (1:1) and showed a substantial variation in nitrogen, phosphorous and potassium contents compared to the control compost. According to Atiyeh et al., [15] earthworms play a major role in nitrogen transformations in manure, by enhancing nitrogen mineralization. The main aim of the present investigation was to know the extent to which flower waste is vermicomposted in order to maximize the potentials of the processes. Earthworms can boost the nitrogen levels of the substrate during digestion in their gut adding their nitrogenous excretory products, mucus, body fluid, enzymes, and even through the decaying dead tissues of worms in vermicomposting subsystem [16]. The vermicompost prepared by the earthworm species showed a substantial difference in total $\mathrm{N}$ content $(P<0.01)$, which could be attributed directly to the species feeding preference of individual earthworm species and indirectly to mutualistic relationship between ingested microorganisms and intestinal mucus [17]. The total $\mathrm{P}$ was higher in the vermicompost harvested at the end of the experiment compared to that of the initial substrate. The enhanced $\mathrm{P}$ level in flower waste vermicompost suggests phosphorous mineralization during the process. The worms during vermicomposting converted the insoluble $\mathrm{P}$ into soluble forms with the help of solubilizing microorganisms through phosphatases present in the gut, making it more available to plants [17]; [18]; [19]. This was buttressed by increased trend of EC showing enhancement of exchangeable soluble salts in vermicompost. Vermicomposting proved to be an efficient process for recovering higher $\mathrm{K}$ from organic waste [17]; [20]. The present findings corroborated to those of [21] who demonstrated that higher K concentration in the end product prepared from sewage sludge.

The increase in $\mathrm{K}$ of the vermicompost in relation to that of the simple compost and substrate was probably because of physical decomposition of organic matter of waste due to biological grinding during passage through the gut, coupled with enzymatic activity in worm's gut, which may have caused its increase. [22] The microorganisms present in the worm's gut probably converted insoluble $\mathrm{K}$ into the soluble form by producing microbial enzymes [23]. Earthworms are sensitive to $\mathrm{pH}$, thus $\mathrm{pH}$ of soil or waste is sometimes a factor that limits the distribution, numbers and species of earthworms. Little information is available on effect of substrate $\mathrm{pH}$ during vermicomposting. The increased trend of $\mathrm{pH}$ in the vermicompost and increase in mineral constituents of waste. The increased EC during the period of the composting and vermicomposting processes is in consistence with that of earlier workers [23]; [24] which was probably due to the degradation of organic matter releasing minerals such as exchangeable $\mathrm{Mg}, \mathrm{K}$, and $\mathrm{P}$ in the available forms, that is, in the form of actions in the vermicompost and compost [25]; [26]. Along with this study, the little increase of body weight was observed. Probably the increase may be due to good nutritional source of vegetable and flower waste. The indigenous species, Eudrilus eugniae, exhibited better growth and reproduction performance is observed. The growth parameters of earthworm species cultured in Vegetable and flower waste showed that the weight increased by $27.5 \%$ in E. eugeniae, in Vegetable waste, while it increased by $49.5 \%$ in E. eugeniae, grown in $\mathrm{FW}$, whereas the in the tartrazine treated the weight was increased slightly. In the flower waste, the weight gain was increased by $49.5 \%$. However, the weight gain was much reduced by 33.64 in the tartrazine treated flower waste compost. The worms when introduced into wastes showed an increased growth rate and reproduction activities.

\section{Conclusion}

In the present study a high degree of organic matter stabilization has been achieved in vermicompost preparation. On the basis of observation, the maturity and organic matter stabilization is found to be higher with vermicompost prepared from vegetable and flower wastes using Eudrilus eugeniae. This study demonstrates the role of earthworms and microbial population which could facilitate rapid decomposition and the rate of mineralization of wastes. The analysis clearly confirms the higher degree of degradation. The mineralization also showed high degree in the compost material. The potential of the species is observed in the analysis of micro and macro nutrients. Similarly, the physical properties also showed promising results in the present work. In the modern context, the formation of wastes increased at large level which can be utilized in a fruitful way by using earthworm for the conversions of varieties of waste into compost material. The present set of investigation is aimed in this direction and the results are encouraging. Researchers reported that the passage of organics through the earthworm's gut significantly alters the physical structure of the material. Large particle are broken down into numerous smaller particles, with a resultant enormous increase in surface area. Soil pollution bioindicators are essential to establish environmental standards. Earthworms and hypogenous micro arthropods were chosen to test ecological risks derived from soil amendment with tartrazine. The objective of culturing earthworms in tartrazine revealed that the earthworm could live in the vegetable and flower waste. In the present investigation the Eudrilus eugeniae, was subjected to various concentrations of vegetable and flower waste. It has been observed that the waste is toxic to earthworms observed only miner damages. The results and the discussions of the present investigation reconfirm the belief that there is no such thing as vegetable and flower wastes only wasted organics. Earthworm can be used to dispose of all sorts of vegetable and flower wastes. The processing of waste by earthworm would help to reduce a major environmental problem, the mounting solid wastes. 


\section{References}

[1]. P.A, Beohar and R.K. Srivasta, Journal of soil science, 1, 2011, 04-11.

[2]. S. Suthar, Journal of Hazardous materials, 16(3): 2009, 199-206.

[3]. T. Wagner and P. Arnold, Journal of Cleaner Production, 16(4): 2008, 410-421.

[4]. A. Nino, A. Rivera, and Ramirez, Journal of Experimental Biology, 2(1): 2012, 199-205.

[5]. D.A, Cox, Journal of plant nutrition, 16, 1993, 533-545.

[6]. C.J. Marlin, K.T. Rajeshkumar, Journal of Applied science research, 3(2), 2012, 1092-1097.

[7]. C.A. Edwards, I. Burrows, The potential of earthworm composts as plant growth media. In: Edwards, C.A., Neuhauser, E. (Eds) Earthworms in Waste and Environmental Management. SPB Academic Press, The Hague: The Netherlands, 1988, 21-32.

[8]. A. Vivas, B. Moreno, S. García-Rodriguez, E. Benítez, Assessing the impact of composting and vermicomposting on bacterial community size and structure, and microbial functional diversity of an olivemill waste. Bioresource Technology, 100: 2009, 13191326 .

[9]. C. Lozano, M. Gomez-Brandón, J. Domínguez, Comparison of the effectiveness of composting and vermicomposting for the biological stabilization of cattle manure. Chemosphere. 72, 2008, 1013-1019.

[10]. M.G. Paoletti, M.R. Favrettoo, B.R. Stinner, F.F. Purrington, and J.E. Bater, Invertebrates as bio-indicators of soil use, Agriculture Ecosystems and Environment, 34: 1991, 341-62.

[11]. P. Sangwan,C.P. Kaushik, V.K. Garg, Waste Management and Research, 28(1): 2010, 71-75.

[12]. M.S. Kitturmath, R.S. Giraddi, B. Basavaraj, Karnataka Journal of Agriculture Science, 20, 2007, $653-654$.

[13]. K.S. Abram, P.R. Ross, Reutilization of spent waste of mushroom industry for vermiculture. Int. J. Res. Biol. Sci. 2 (3), 2012, 120123 .

[14]. M. Jayakumar, T. Sivakami, D. Ambika, N. Karmegam, Effect of turkey litter (Meleagrisgallopavo L.) vermicompost on growth and yield characteristics of paddy, Oryzasativa (ADT-37), African J. Biotech., 10:(68), 2011, 15295-15304.

[15]. R.M. Atiyeh, J. Dominguez, S. Subler, C.A. Edwards, Changes in biochemical properties of cow manure during processing by earthworms (Eugenia andrei Bouche) and the effects on seedling growth. Pedobiologia 44, 2000, 709-724.

[16]. S. Suthar, Nutrient changes and biodynamics of epigeic earthworm Perionyx excavates (Perrier) during recycling of some agriculture wastes, Bioresource Technology, 98(8): 2007, 1608-1614.

[17]. S. Suthar, and S. Singh, Vermicomposting of domestic waste by using two epigeic earthworms (Perionyx excavatus and Perionyx sansibaricus), International Journal of Environment Science and Technology, 5(1): 2008, 99-106.

[18]. P.K. Padmavathiamma, L.Y. Li, and U.R. Kumari, An experimental study of vermi-bio-waste composting for agricultural soil improvement, Bioresource Technology, 99(6): 2008, 1672-1681.

[19]. M, Ghosh, G.N. Chattopadhyay, and K. Baral, Transformation of phosphorus during vermicomposting. Bio resource Technology, 69, 1999, 149-154.

[20]. M.C. Manna, S. Jha, P.K. Ghosh, and C.I. Acharya, Comparative efficiency of three epigeic earthworm under different deciduous forest litters decomposition. Bioresource Tech., 88(3): 2003, 197-206.

[21]. M. Delgado, M. Bigeriego, I. Walter, and R, Calbo, Use of California red worm in sewage sludge transformation, Turrialba, 45, 1995, 33-41.

[22]. S. Rao, A.S. Rao. and P.N. Takkar, Changes in different forms of under earthworm activity in Proceedings of the National Seminar on Organic Farming and Sustainable Agriculture, 1996, 9-11, Ghaziabad, India, October.

[23]. Kaviraj and S. Sharma, Municipal solid waste management through vermicomposting employing exotic and local species of earthworms, Bioresource 'Technology, 90:(2), 2003, 169-173.

[24]. C.D. Jaida, and M.H. Fulekar, Vermicomposting of vegetable waste: a bio-physicochemical process based on hydro operating bioreactor, African Journal of Biotechnology, 7,2008, 3723-3730.

[25]. L.F. Guoxue, Y. Zhang, J.W.C. Sun, Wong, and M. Fang, Chemical evaluation of sewage composting as mature indicator for composting process, Water Air Soil Sludge Pollution, 132, 2001, 333-345.

[26]. C. Tognetti, F. Laos. M.J. Mazzarino, and M.T. Hernandez, Composting vs. vermicomposting: a comparison of end product quality, Compost Science and Utilization, 13(1), 2005, 6-13. 